\title{
IMPROVING THE DYNAMICS OF AN INVERTER-BASED PV GENERATOR DURING LOAD DUMPS
}

\author{
Lukasz Kwaśny \\ Lublin University of Technology, Faculty of Electrical Engineering and Computer Science, Department of Electrical Drives and Machines, Lublin, Poland
}

Abstract. In distribution power grids supplied by dispersed power sources, for example RES (Renewable Energy Sources), in the event of a load dump, unexpected transient states may appear. These states involve a dangerous increase in voltage or current. This situation may lead to the disconnection of these sources. To prevent this phenomenon, a non-linear anti-windup regulator with a conditional integrator has been proposed. This solution allows a significant improvement of the generator's dynamic properties both at load dump and on return to full load.

Keywords: load dump, dynamic states, anti-windup regulator, conditional integrator

\section{POPRAWA DYNAMIKI PRZEKSZTALTNIKOWEGO GENERATORA PV PODCZAS ZRZUTU MOCY}

Streszczenie. W sieciach dystrybucyjnych o rozproszonym charakterze zasilania, np. OZE (Odnawialne Źródła Energii), w przypadku wystapienia zrzutów mocy moga pojawić się nieoczekiwane stany nieustalone. Polegają one na niebezpiecznym wzroście napięcia lub prądu. Taka sytuacja może doprowadzić do wyłaczenia tych źródel energii. Aby temu zapobiec, zaproponowano nieliniowy regulator anti-windup z warunkowym integratorem. Rozwiąanie to pozwolito zdecydowanie poprawić własności dynamiczne zarówno przy zrzucie mocy jak i powrocie do petnego obciązenia.

Słowa kluczowe: zrzut mocy, stan nieustalony, regulator anti-windup, całkowanie warunkowe

\section{Introduction}

Affordable prices, availability and relatively low installation costs of renewable energy sources contribute towards increase of distributed generation share in the energy market. Unfortunately, this trend can cause issues with keeping electrical energy quality within approved boundaries both during static and dynamic states.

The cause of dynamic states are either changes in reference values, or any kind of disturbances affecting control or measurement signals. This paper presents dynamic states caused by load dumps. It shows the characteristics of this kind of disturbance and the consequences that follow. It is proven that the key role in reducing voltage increase during load dumps is played by the power regulator. Thus, selection of this regulator is the research goal of this paper.

A load dump is always accompanied by a change of load parameters. Such a state of systems supplied by renewable generation requires a nonlinear regulator in the power control circuit. The idea of controller proposed by the author implements a logical condition which allows the regulator to avoid saturation of an integral path. This paper presents mathematical models of regulators, research methodology, and finally - laboratory results.

\section{Load changes}

The increasing number of PV inverters in the electrical grid has highlighted the problem of keeping energy parameters within boundaries set by normative acts. Disturbances, known in the literature as transient or temporary over-voltage (TOV) are especially visible during PV inverter operation [7]. They are especially dangerous for the electrical equipment operating in the grid with the high density of PV generators. There are two main causes of voltage increase:

- Load rejection overvoltage (LRO) [7] (Fig.1),

- Ground fault overvoltage (GFO) [1, 4].

Negative effects can be partially solved by installing a DC/DC converter in the intermediate circuit [2] or adding an active load output [9]. However, these solutions give only partial effects, since a rapid full load return will cause even more problems. These would include short voltage drops or rapid current increase on inverter output. These phenomena often cause the action of overcurrent protection, and as a result - a shutdown of the entire generator [5].

Disturbances caused by load dump can be eliminated by means of nonlinear regulators with conditional operating functions, so called "PI conditional integrators", which are described in further chapter.

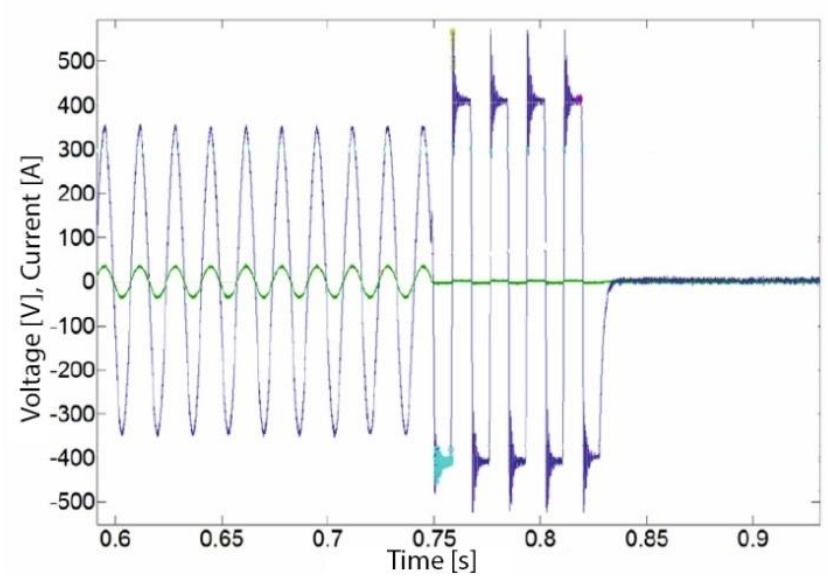

Fig. 1. Exemplary results of current and voltage measurements during load dump in $t=0.075 \mathrm{~s}$. Overvoltage level $V_{\max } / V_{\text {amp }}=1.75$ achieved for $10 \%$ load dump

\section{Vector control with decoupling}

During the research an inverter with voltage oriented control (VOC) (Fig. 2) was used [7, 8].

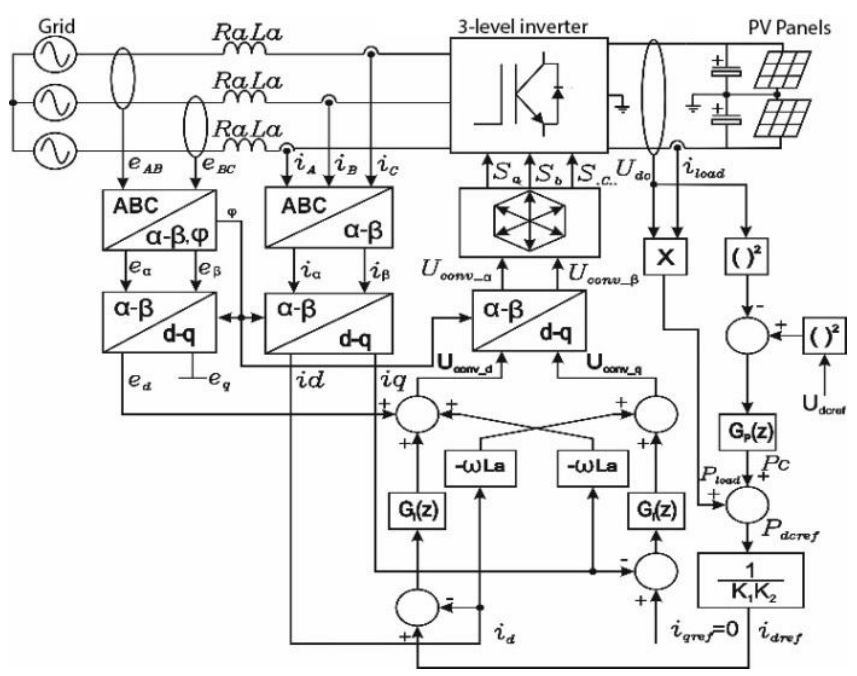

Fig. 2. Vector oriented control with decoupling in current paths $i_{d}, i_{q}$ in rotating reference frame $d_{q}$ 
In this system input voltages for the $\mathrm{d}-\mathrm{q} \rightarrow \alpha-\beta$ transform are described in equations (1) and (2), which also explain the decoupling method.

$$
\begin{gathered}
U_{c o n v_{-} d}=\left(i_{d r e f}-i_{d}\right) \cdot G(z)+e_{d}+-\omega L_{g} i_{d} \mathrm{U}_{\text {conv }_{-} \mathrm{d}}= \\
\quad\left(\mathrm{i}_{\mathrm{dref}}-\mathrm{i}_{\mathrm{d}}\right) \cdot \mathrm{G}(\mathrm{z})+\mathrm{e}_{\mathrm{d}}+-\omega \mathrm{L}_{\mathrm{g}} \mathrm{i}_{\mathrm{d}} \\
U_{\text {conv } q}=\left[\left(i_{\text {qref }}-i_{q}\right) \cdot G(z)\right]-\omega L_{g} i_{q}
\end{gathered}
$$

where: $i_{\text {dref }}, i_{\text {qref }}$-reference currents, $i_{d}, i_{q}$ - mesured currents, $G(z)$ - discrete controller transfer function, $\omega L_{g} i_{d}, \omega L_{g} i_{q}-$ voltage drops across inductor.

In the $\mathrm{d}-\mathrm{q}$ input paths there are $\mathrm{G}_{\mathrm{I}}(\mathrm{z})$ controllers, which allow independent control over instantaneous powers $p$ and $q$. Selection of control algorithm influences the characteristics of dynamic states. This is shown in experimental results, during which three different PI algorithms were used:

- Standard, parallel PI regulator,

- Nonlinear, variable-structure regulator:

- Regulator with "anti-windup" algorithm,

- Regulator with conditional integrator.

These regulators are tasked with minimising error in the $i_{d}$ and $i_{q}$ current paths. This is achieved by tuning both proportional and integral gains of the regulators, and placing them in current paths, as shown in Fig. 2.

\section{PI controller tuning method}

In order to achieve the dynamics requirements of the inverter, as well as provide an appropriate phase margin, PI controller tuning was performed. This stage was based on literature [6]. The tuning is presented on the current feedback loop $i_{s q}$ and shown in Fig. 3.

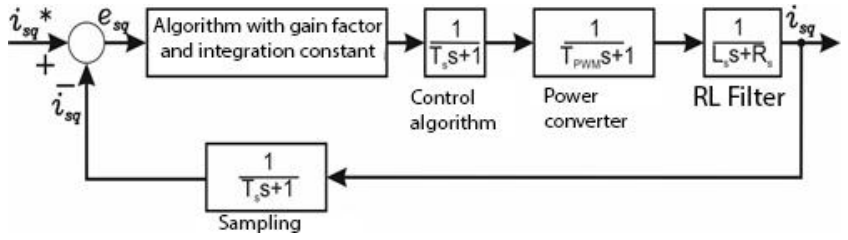

Fig. 3. Model of current control loop in q axis with simulated object and measurement characteristics

In this case, the delay caused by digital conversion was described as a first order transfer function with time coefficient $\mathrm{T}_{\mathrm{s}}=0.1 \mathrm{~ms}$, for sampling frequency $f_{s}=10 \mathrm{kHz}$. To keep the power losses in IGBT switches at a minimum level, the time delay of $\mathrm{T}_{\mathrm{PWM}}=0.1 \mathrm{~ms}$ was selected. Voltage and current measurements are slaved of PWM modules, which also causes the delay of analogue-digital conversion to be at $T_{\mathrm{s}}=0.1 \mathrm{~ms}$. The transfer function of the PI regulator is described in equation (3) [6].

$$
\mathrm{PI}_{\mathrm{iq}}=\mathrm{k}_{\text {piq }}\left(1+\frac{1}{\mathrm{~T}_{\mathrm{iq}} \mathrm{s}}\right)=\mathrm{k}_{\text {piq }} \frac{1+\mathrm{T}_{\mathrm{iq}} \mathrm{s}}{\mathrm{T}_{\mathrm{iq}} \mathrm{s}}
$$

where: $k_{\text {piq }}$ - proportional gain of current path $i_{q}, T_{i q}$-time coefficient of the integration path of current $i_{q}$

$$
\frac{\mathrm{i}_{\mathrm{sq}}}{\mathrm{v}_{\mathrm{sq}}}=\frac{1}{\mathrm{R}_{\mathrm{s}}+\mathrm{sL}_{\mathrm{s}}}=\frac{1}{\mathrm{R}_{\mathrm{s}}} \frac{1}{1+\mathrm{s} \frac{\mathrm{L}_{\mathrm{q}}}{\mathrm{R}_{\mathrm{s}}}}=\frac{\mathrm{K}}{1+\mathrm{s} \cdot \tau_{\mathrm{q}}}
$$

where:

$$
\begin{aligned}
\mathrm{K} & =\frac{1}{\mathrm{R}_{\mathrm{s}}} \\
\tau_{\mathrm{q}}=\frac{\mathrm{L}_{\mathrm{q}}}{\mathrm{R}_{\mathrm{s}}} & =0,025[\mathrm{~s}]
\end{aligned}
$$

The transfer function in a closed feedback loop was converted into feedforward. The transformed current loop is shown in Figure 4.

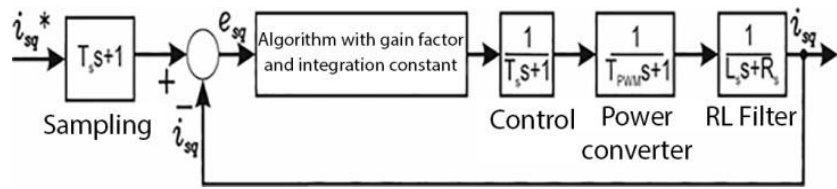

Fig. 4. Model of $i_{q}$ current control loop with feedforward
The transfer function of the object in open loop is described in equation (7)

$$
\mathrm{G}_{\mathrm{iq}}(\mathrm{s})=\mathrm{k}_{\mathrm{piq}} \frac{1+\mathrm{T}_{\mathrm{iq}} \mathrm{s}}{\mathrm{T}_{\mathrm{iq}} \mathrm{s}} \frac{\mathrm{K}}{\tau_{\mathrm{q}} \mathrm{s}+1} \frac{1}{\mathrm{~T}_{\mathrm{s}} \mathrm{s}+1} \frac{1}{\mathrm{~T}_{\mathrm{s}} \mathrm{s}+1} \frac{1}{\mathrm{~T}_{\mathrm{PWM}} \mathrm{s}+1}
$$

The time coefficient of the PI regulator is selected to compensate the slowest pole of the objects' transfer function, which is approximately defined by the $\mathrm{L} / \mathrm{R}$ filter coefficient.

$$
\mathrm{T}_{\mathrm{si}}=2 \mathrm{~T}_{\mathrm{s}}+\mathrm{T}_{\mathrm{PWM}}=0.2+0.1=0.3[\mathrm{~ms}]
$$

From here, the transfer function of the entire object:

$$
\mathrm{G}_{\mathrm{iq}}(\mathrm{s})=\mathrm{k}_{\mathrm{piq}} \frac{1}{\mathrm{~T}_{\mathrm{iq}} \mathrm{s}} \mathrm{K} \frac{1}{\mathrm{~T}_{\mathrm{si}} \mathrm{s}+1}
$$

The $k_{\text {piq }}$ gain of the PI regulator was calculated on the basis of the modulus optimum (KM). The damping coefficient was selected on the basis of [6] and its value is $\zeta=\frac{\sqrt{2}}{2}$. The transfer function of the second object is described in equation (10).

$$
\mathrm{G}_{\mathrm{KM}}=\frac{1}{2 \tau \mathrm{s}(\tau \mathrm{\tau}+1)}
$$

Converting equations (9) and (10)

$$
\begin{gathered}
\frac{\mathrm{k}_{\mathrm{piq}} \mathrm{K}}{\mathrm{T}_{\mathrm{iq}}}=\frac{1}{2 \mathrm{~T}_{\mathrm{is}}} \\
\mathrm{k}_{\mathrm{piq}}=\frac{\mathrm{T}_{\mathrm{iq}} \mathrm{R}_{\mathrm{s}}}{2 \mathrm{~T}_{\mathrm{si}}}=47,87
\end{gathered}
$$

The regulators tuned in the way described were transformed into discrete functions using Matlab software. Compilation results were implemented in the tested regulators. The results are presented in Figure 8.

\section{Nonlinear PI regulators with variable internal structure}

During rapid load changes, overshoot of the converter can be limited by means of modified, nonlinear PI regulator.

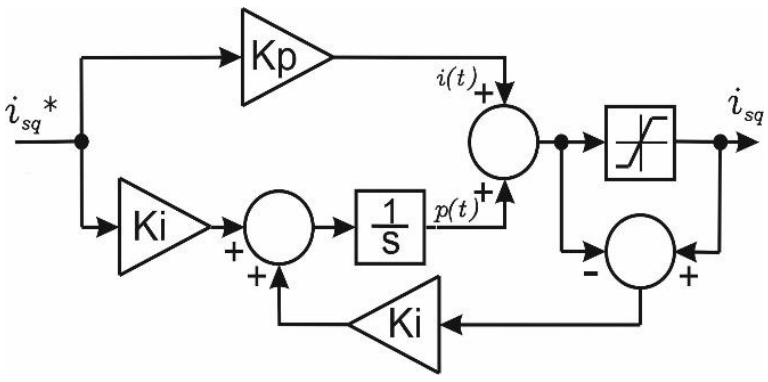

Fig. 5. Nonlinear PI regulator, with "anti-windup" function. Kp, Ki regulator gains, $K s$-feedback gain, $I_{s q}{ }^{*}$ - reference current

The algorithm that deals with overshoot and saturation is shown in Figure 5. When the regulator output becomes saturated, the difference between saturation block input and output occurs. This difference is then amplified in the Ki block, and then subtracted in the sum block of the integration path.

Unfortunately, the dynamics of such a regulator is still insufficient in the case of rapid load changes (Fig. 9). Because of this, a nonlinear algorithm with logical condition and feedback loop was proposed (Fig. 6)

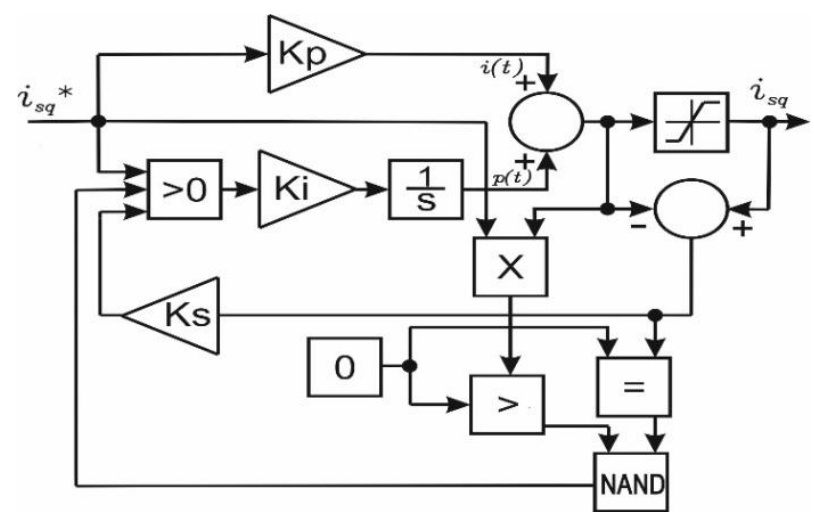

Fig. 6. Nonlinear PI algorithm, with logically controlled strong feedback loop 
This implemented feedback loop causes almost immediate return from the saturated state of the algorithm (Fig. 10). The NAND logic gate based system controls the output and checks it for saturation

\section{Experimental results}

During experimental research, a VOC controlled inverter was loaded by an electrical grid emulator [3, 10]. The influence of a load dump on converter output voltage at grid connection point was tested on the basis of previously derived control algorithms.

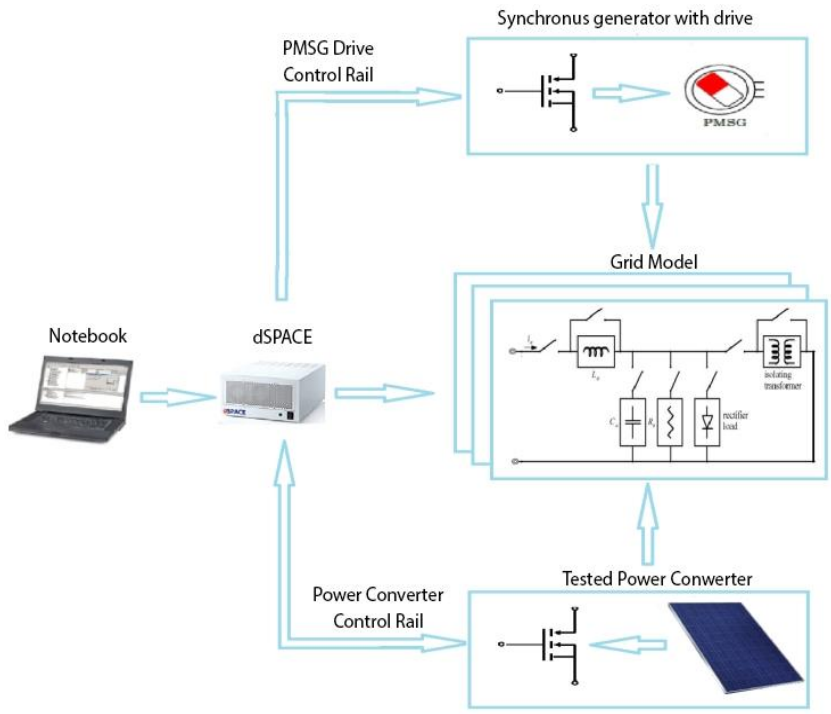

Fig. 7. Simplified diagram of electric grid emulator

The emulator used consists of a synchronous generator PMSG with output power of $5.5 \mathrm{~kW}$, which is driven by a squirrel cage motor and vector oriented inverter. This machine system produces three-phase voltage similar in parameters to the one provided by the grid. A load dump is created by means of changing impedance in the intermediate circuit between the PMSG generator and tested inverter. These changes are performed by a relay matrix. Selected RL elements allow for step increases or decreases of the intermediate circuit impedance. In this way, a load dump was created, reaching $20 \%$ of generator nominal power.

Experimental tests were performed for the three aforementioned PI regulators. Activation levels of logical conditions were experimentally selected to achieve the best possible time responses of algorithms. A typical PI algorithm is a sufficient solution when the output power is controlled only by the user. However, in the case of a load dump, and then a return to nominal load, it causes an inverter output power overshoot (Fig. 8).

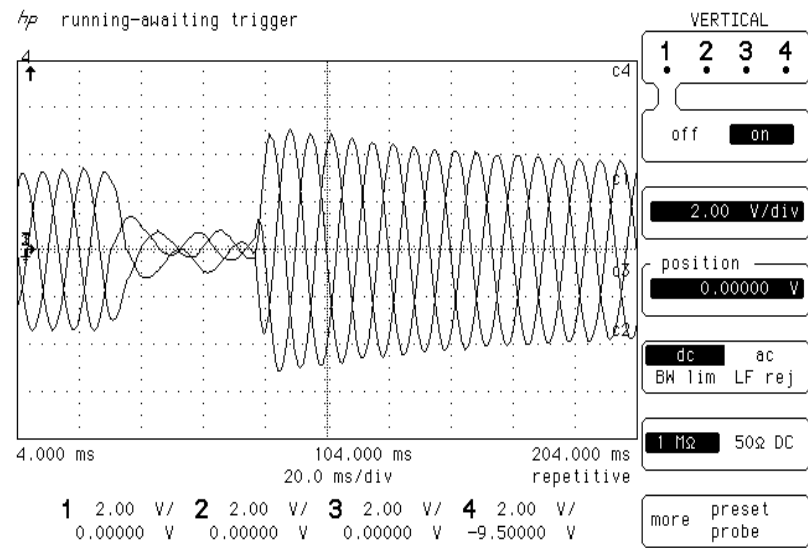

Fig. 8. Current waveforms during load dump with standard PI algorithm. Current scale: $5 \mathrm{~A} / \mathrm{lV}$
The inverter produces power, which can be a multiple of reference power at the moment of load return. In the model tested, doubling of output power was achieved for a load dump lasting $0.1 \mathrm{~s}$. The time required for the output power to stabilize at reference level was $0.4 \mathrm{~s}$.

In the case of a PI algorithm with "anti-windup" function, results presented in Figure 10 were obtained. Response for a load dump had increased time to return to nominal value.

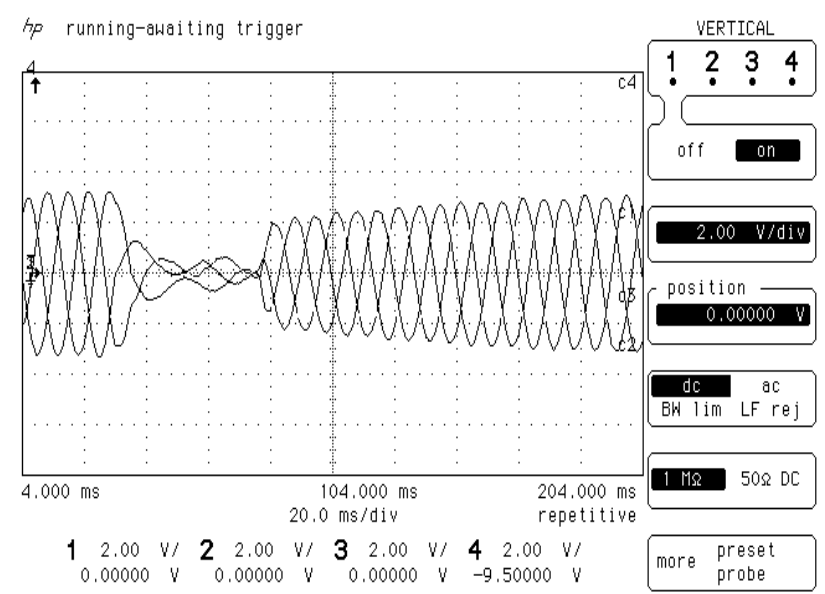

Fig. 9. Current waveforms during load dump with PI algorithm with "anti-windup" function. Current scale: $5 \mathrm{~A} / \mathrm{lV}$

A slow return to reference output power does not cause short term overloads, but it constitutes too large a delay in return to nominal load. This delay can cause an impermissible voltage drop at the local grid, which can in turn result in a shutdown of certain loads or even of PV generation inverters.

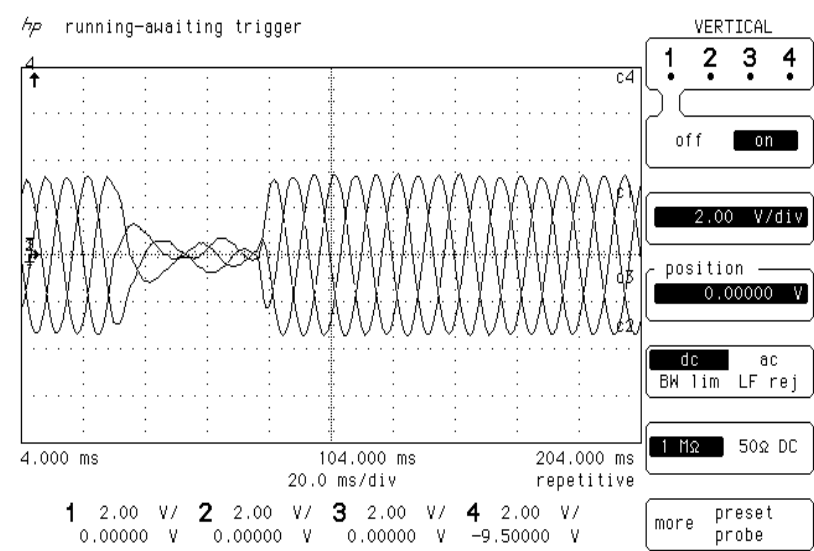

Fig. 10. Current waveforms during load dump with PI algorithms with strong feedback loop. Current scale: $5 \mathrm{~A} / \mathrm{lV}$

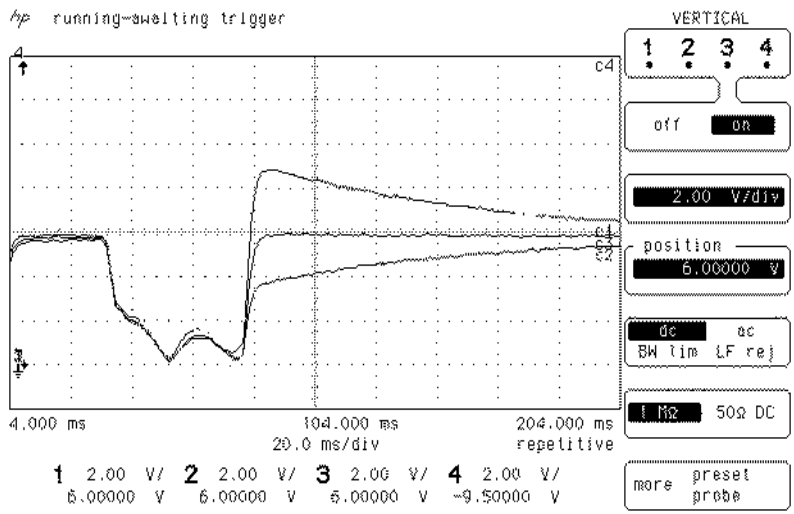

Fig. 11. Output current modulus from inverter to emulated grid for three different PI algorithms. Current scale: $5 \mathrm{~A} / \mathrm{lV}$ 
The best results were achieved in the case of a PI algorithm with conditional integration. The response of this algorithm was almost instantaneous (Fig. 10). Multiple tests with different load changes proved that for this type of disturbances this algorithm is the most efficient. Overshoot never crossed 5\% of output current reference value. This is due to the fact that as soon as regulator output becomes saturated, the entire integration path is reset to zero. This situation lasts as long as the controller output stays saturated. Because of this, the algorithm is not pushed into further saturation, and can recover its dynamics very fast.

A comparison of all three results is presented on a single graph in Figure 11. This figure proves that the best result was achieved using the third algorithm - a PI algorithm with conditional integration loop.

Table 1. W Experimental results and reset quality coefficients for three PI algorithms

\begin{tabular}{|c|c|c|c|c|c|}
\hline Algorithm & $\begin{array}{c}\text { Control } \\
\text { precison }\end{array}$ & Overshoot & $\begin{array}{c}\text { Error } \\
\text { integral } \\
\mathrm{I}_{\mathrm{d}}\end{array}$ & $\begin{array}{c}\text { Error } \\
\text { integral } \\
\mathrm{I}_{\mathrm{q}}\end{array}$ & $\begin{array}{c}\text { Response } \\
\text { curve }\end{array}$ \\
\hline $\begin{array}{c}\text { PI } \\
(1)\end{array}$ & Very good & $>100 \%$ & $58 \%$ & 2.5 & \\
\hline $\begin{array}{c}\text { PI_N } \\
(2)\end{array}$ & Very good & $\begin{array}{c}\text { no } \\
\text { overshoot }\end{array}$ & $41.3 \%$ & $1, .8$ & \\
\hline $\begin{array}{c}\text { PI_N } \\
(3)\end{array}$ & Very good & $<5 \%$ & $37.2 \%$ & 1.49 & \\
\hline
\end{tabular}

\section{Conclusions}

The load dump problem in an electrical grid becomes more relevant with the increasing number of renewable energy sources in households. The author proposed a solution to this problem by using a nonlinear control algorithm in the current control circuits of renewable generation inverters. The proposed algorithm eliminates such unwanted effects as wind-up saturation. Also, it does not affect generation capability during return to nominal load. Through this, the article's goal was achieved, and the current ripple was reduced to below $5 \%$. The dynamic state duration was also reduced.

\section{References}

[1] Barker P.: Overvoltage considerations in applying distributed resources on power systems. IEEE Power Engineering Society Summer Meeting 1/2002, $109-114$.

[2] Huang S., Wu J.: A control algorithm for three-phase three-wired active power filters under nonideal mains voltages. IEEE Transactions on Power Electronics 14(4)/1999, 753-760.

[3] Jarzyna W., Lipnicki P., Zieliński D.: Synchronisation of voltage frequency converters with the grid in the presence of notching. COMPEL - The International Journal for Computation and Mathematics in Electrical and Electronic Engineering 34(3)/2015, 657-673, [DOI: 10.1108/COMPEL-102014-0266].

[4] Jarzyna W., Lipnicki P.: The Comparison of Polish Grid Codes to Certain European Standards and resultant Differences for WPP Requirements. 15th European Conference on Power Electronics and Applications (EPE), 1-6, [DOI: 10.1109/EPE.2013.6634748].

[5] Jarzyna W., Zieliński D., Zielińska K., Fatyga K.: Reduction of voltage and power oscillation in the two-phase shorting of a grid inverter. 19th European Conference on Power Electronics and Applications (EPE'17 ECCE Europe) 2017.

[6] Kaźmierkowski M. P., Tunia H.: Automatic Control of Converter-Fed Drives. Elsevier, 1995.

[7] Ropp M.: Inverter grounding and overvoltages. IEEE PES General Meeting, 2014.

[8] Sedlak M., Styński S., Kaźmierkowski M. P., Malinowski M.: Operation of a four-leg three-level flying capacitor grid-connected converter for RES. IECON 2013 - 39th Annual Conference of the IEEE Industrial Electronics Society, 2013, 1100-1105, [DOI: 10.1109/IECON.2013.6699286].

[9] Teodorescu R., Lissere M., Rodriguez P.: Grid Converter for Photovoltaic and Wind Power Systems. IEEE-Wiley, New York 2011.

[10] Zieliński D.: A laboratory system for analysing power inverters during voltage sags. Informatyka, Automatyka, Pomiary w Gospodarce i Ochronie Środowiska 4(2)/2014, 77-80, [DOI: 10.5604/20830157.1109384].

\section{M.Sc. Eng. Lukasz Kwaśny}

e-mail: 1.kwasny@pollub.pl

Graduated from the Faculty of Electrical Engineering and Computer Science. Since 2016 employed at the Department of Electrical Drives and Machines of the Lublin University of Technology. His interests include power electronics, especially design and modelling of converters for grid-tied applications and renewable energy generation interfaces.

ORCID ID: 0000-0001-7454-9862

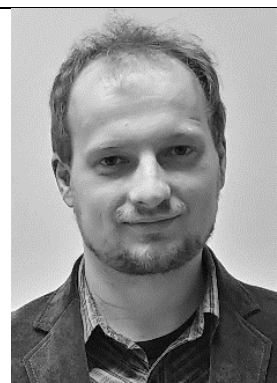

otrzymano/received: 01.08.2019 przyjęto do druku/accepted: 06.12.2019 